\title{
Introduction of an Automated System for the Diagnosis and Quantification of Hepatitis B and Hepatitis C Viruses
}

\author{
M.T. Cabezas-Fernandez ${ }^{*}$ and M.I. Cabeza-Barrera
}

APES Hospital Poniente, Spain

\begin{abstract}
Hepatitis B virus (HBV) and Hepatitis C virus (HCV) infections pose major public health problems because of their prevalence worldwide. Consequently, screening for these infections is an important part of routine laboratory activity. Serological and molecular markers are key elements in diagnosis, prognosis and treatment monitoring for HBV and HCV infections. Today, automated chemiluminescence immunoassay (CLIA) analyzers are widely used for virological diagnosis, particularly in high-volume clinical laboratories. Molecular biology techniques are routinely used to detect and quantify viral genomes as well as to analyze their sequence; in order to determine their genotype and detect resistance to antiviral drugs. Real-time PCR, which provides high sensitivity and a broad dynamic range, has gradually replaced other signal and target amplification technologies for the quantification and detection of nucleic acid. The nextgeneration DNA sequencing techniques are still restricted to research laboratories.
\end{abstract}

The serological and molecular marker methods available for HBV and HCV are discussed in this article, along with their utility and limitations for use in Chronic Hepatitis B (CHB) diagnosis and monitoring.

Keywords: DNA-HBV, Real-time, genotyping, RNA-HCV, TMA, serological markers.

\section{HBV (HEPATITIS B VIRUS)}

Hepatitis B virus (HBV) infection is a global health problem; approximately 2 billion people in the world have been infected by $\mathrm{HBV}$, and more than 350 million are chronic carriers of the virus. HBV infection accounts annually for 1 million deaths worldwide from cirrhosis, liver failure, and hepato cellular carcinoma [1,2]. The infection is present mainly in countries in the Middle-East and SouthEast Asia, sub-Saharan Africa, Central and South-America, and Eastern Europe with a population prevalence of $>8 \%$ [1]. Over the last twenty years, a migratory flow has been taking place from these countries to industrialized countries (the USA and Western Europe) with an increase of some infectious diseases (HIV, TB, viral hepatitis) $[3,4]$.

Human HBV is a member of the Hepadnaviridae family and humans and higher primates are the only hosts for HBV infection. The intact viron comprises the viral DNA surrounded by a nucleocapsid (core protein or antigen) and an outer layer comprising the HBV surface protein or antigen (HBsAg). The viral genome is a $3.2-\mathrm{kb}$ partially double-stranded DNA with four overlapping reading frames (ORF). The viral genome encodes the viral polymerase (which includes the reverse transcriptase function), the core and surface proteins, and the non-structural proteins (HBV e antigen and $\mathrm{X}$ protein). The cccDNA (co-valently closed circular DNA), which acts as the major transcriptional template for the virus, is central to the durability of HBV infection and persists as an episome in infected hepatocytes.

*Address correspondence to this author at the APES Hospital Poniente, Spain; Tel: 950022638; Fax: 950022601;

E-mails: tcabezasf@yahoo.es, cbmisa@yahoo.es
It can persist after antiviral therapy and even after the apparent clearance of the infection [5].

Eight genotypes (A-H) of HBV have been identified based on nucleotide sequence divergences of at least $8 \%$. HBV genotypes differ in their predominant geographical occurrence and also in their response to interferon therapy. Genotype A is the predominant genotype in the United States and is more responsive to interferon than genotype D which predominates in the Middle East and South Asia [6].

\subsection{Serological Diagnosis}

Serological HBV diagnosis can be accomplished by identifying virally-encoded antigens and their corresponding antibodies: $\mathrm{HBsAg}$, anti-HBs, $\mathrm{HBeAg}$, anti-HBe, and anti$\mathrm{HBc}$. (HBcAg does not circulate freely in the serum) [7]

Today, automated chemiluminescence immunoassay (CLIA) analyzers are gradually replacing the EIA and are widely used, particularly in high-volume clinical laboratories. They offer the great advantages of improved precision, reliability, technical simplicity, rapid turnaround time, high-speed throughput, and full automation [8-10].

B surface antigen (HBsAg) is a key marker for the screening and laboratory diagnosis of HBV infection and the first serological marker to appear during the course of HBV infection. HBsAg sensitivity depends on the detection threshold of immunoassays $[8,9]$. Newly-developed HBsAg assays show a performance increase in terms of specificity and sensitivity, allowing the detection of $<0.15 \mathrm{ng} / \mathrm{ml}$ of HbsAg [10].

Because of the genetic diversity of HBV, the sensitivity of HBsAg assays may also be dependent on $\mathrm{HBsAg}$ antigenic variation, the most relevant mutations in the 
HBsAg gene are amino acid substitutions at positions 145, 141 , and 131 in the major "a" determinant and insertions between amino acids 122 and 123. In fact, some HBsAg mutants that emerge after selection by immune pressure can escape detection by commercial HBsAg assays. In addition, there is natural heterogeneity in HBV due to genotype and subtype diversity. To ensure high sensitivity and reduce the risk of false negative results, immunoassays must be able to detect the most commonly found viral mutants [11-13].

\subsection{1. qHBsAg Assays}

In addition to its use as a qualitative marker, recent innovations have allowed for the quantitative assessment of HBsAg (qHBsAg) in serum. The clinical relevance of HBsAg levels is derived from its correlation with intrahepatic HBV co-valently closed circular (ccc) DNA, the main replicative template of $\mathrm{HBV}[2,3]$. Through this association, serum HBsAg is hypothesized to be a marker for immunological response to therapy, independent of virological response as measured by HBV DNA levels [14].

Currently, multiple diagnostic assays are available for quantification of HBsAg. The most widely used is the Architect assay, but HBsAg quantification may also be performed using the Elecsys platform (HBsAg Quant Package Insert, Roche Diagnostics 2011) [15-17].

\subsection{2. $\mathrm{AgHBCr}$}

The measurement of serum HBV core antigen ( $\mathrm{HBcAg}$ ) levels has been problematic because it is localized to the infected hepatic tissues and not released into the blood. A new assay was developed for measuring HBV core-related antigen (HBcrAg), which consists of a core, e antigen ( $\mathrm{HBe} A g)$, and the precore $\mathrm{HBV}$ proteins $(22-\mathrm{kD}$ precore fragment, amino acids 28-150); HBcrAg levels correlated well with HBV DNA levels [15]. A recent study showed that the serum HBcrAg concentration was related to the level of intrahepatic cccDNA [16]. Until recently, and for more than a decade, only 1 commercial qHBsAg assay was available [15].

\subsection{Molecular Markers}

Measurement of HBV levels in serum is a reliable marker for the prognosis of acute and chronic infection and allows one to predict the success of antiviral therapy as well as to identify the development of drug resistance [18-21].

Clinical practice guidelines for the management of chronic hepatitis B [22], recommend the quantification of HBV DNA in the initial evaluation of chronic hepatitis B and during management, particularly in the decision taken to initiate treatment and in therapeutic monitoring. Highsensitivity molecular assays are clearly important for the diagnosis of $\mathrm{HBeAg}-\mathrm{CHB}$ and occult $\mathrm{HBV}$, where viral loads can be quite low.

Four types of molecular assays are available for the diagnosis and management of HBV infection: quantitative viral load tests, genotyping assays, drug resistance mutation tests, and core promoter/precore mutation assays [23].

\subsubsection{Molecular Tests for HBV Quantification}

Several hybridization and amplification-based methods have been described for HBV DNA quantitation. First- generation assays for HBV DNA quantification in peripheral blood (usually serum or plasma) were based on solution hybridization technology (this assay was relatively insensitive -approximately $5.0 \log 10 \quad$ copies $/ \mathrm{ml}$, and its linearity ranged from 5.0 to $10.0 \log 10$ copies/ $\mathrm{ml}$. The adaptation of advanced molecular technologies, such as signal and target amplification, led to the development of second-generation assays with enhanced sensitivity (as low as 200 copies/ml) [24,25].

1.2.1.1. Hybridization Methods: Hybrid Capture Technology and the Branched DNA Assay

HBV-DNA is hybridized with a HBV RNA probe. The DNA-RNA hybrids are immobilized onto a microtiter plate using anti-DNA-RNA antibodies. Antihybrid antibodies conjugated to an enzyme are used for detection in combination with appropriate chemiluminescent substrates $[23,24]$.

For the branched DNA (bDNA) assay, HBV-specific probes are used to capture HBV DNA in the sample on the microtiter plates. Subsequently, extender probes, bDNA and dioxetane substrate, are used for detection and the bDNA molecules serve as signal amplification molecules [23,25].

\subsubsection{Target Amplification Methods}

\subsection{Quantitative-competitive PCR}

For quantitative-competitive PCR (Amplicor HBV MONITOR $^{\circledR}$ [Roche Diagnostics, NJ, USA]), an internal standard (IS) is co-amplified with HBV DNA in the sample a non-nested PCR. Serial dilution is conducted and the PCR product is separately hybridized with $\mathrm{HBV}$-specific or ISspecific probes on a microtiter plate. The hybridized PCR product is detected colorimetrically and the HBV DNA concentration in the sample is determined based on the ratio of HBV specific and IS-specific signals. The sensitivity of this assay can detect as few as 200 copies/ml $[23,26]$.

\subsection{Real-time PCR}

The latest generation HBV quantification assays utilize real-time PCR and have improved analytical performance characteristics, including low limits of detection, ability to quantify the wide range of HBV DNA concentrations that occur in patients, and excellent precision. It's the method recommended in the current American Association for the Study of Liver Diseases (AASLD) guidelines [22].

Quantification by real-time PCR is based on the determination of the threshold cycle $(T C)$ when the amplified product is detected for the first time and the PCR is still in the exponential phase.

In order to ensure comparability between the assays, HBV DNA levels should be universally reported in $\mathrm{IU} / \mathrm{ml}$, which have been calibrated using the World Health Organization (WHO) international standard for HBV DNA [22]. In therapeutic HBV monitoring, a more sensitive assay with a lower limit of detection (LLOD) of $10 \mathrm{IU} / \mathrm{ml}$ is recommended for early detection of viral rebound. In addition, the assay employed should equally quantify all HBV genotypes. HBV DNA assays need further improvement to increase their upper limit of quantification (LLOQ) clinicians frequently encounter patients (particularly 
those who are immunotolerant) with levels of HBV DNA much higher than $10^{8} \mathrm{IU} / \mathrm{mL}[20,21]$.

The real-time PCR assays typically incorporate robotic automation, making them attractive for high-throughput laboratories. These techniques decrease the potential for cross-contamination by assay-generated amplicons due to the closed-tube nature of the assays; they also use dUTP/uracil$\mathrm{N}$-glycosylase in the master mixture, further decreasing the theoretical risk of contamination caused by the amplification tube being compromised $[27,28]$.

Commercially available quantitative assays use a variety of different detection methods and are summarized in Table 1.

Additionally, several in-house quantitative assays for HBV-DNA have been developed, based mostly on real-time PCR methodology, showing remarkable sensitivity and a wide linear quantification range [29], with an ultra-sensitive in-house RTQ-PCR performed in a LightCycler $^{\circledR} 2.0$ instrument (Roche, Molecular Biochemicals, Mannheim, Germany). The new assay showed improved sensitivity of 22 and $8 \mathrm{IU} / \mathrm{mL}$ as $95 \%$ and $50 \%$ detection end-points.

\subsubsection{HBV Genotyping Methods}

Several genotyping methods have been described, based mainly on sequencing, restriction fragment length polymorphism (RFLP), PCR with genotype-specific primers, line probe assay, or real-time PCR [30-33].

\subsubsection{Sequencing and Phylogenetic Analysis}

The most accurate method for hepatitis B virus (HBV) genotyping [34,35] is based on phylogenetic analysis following DNA sequencing of the entire viral genome, often restricted to the $\mathrm{S}$ gene [36]. This is the gold standard of HBV genotyping, the technique is highly sensitive and allows the detection of new and recombinant genotypes, but it is considered to be technically challenging, timeconsuming, and costly; and cannot be used in large-scale studies. Furthermore, in the case of multiple-genotype infection, only the most abundant genotype is identified [36].

A commercial direct-sequencing assay kit is available (TRUGENE HBV Genotyping Kit; Siemens Medical Solutions Diagnostics, NY, USA). Both genotypes and HBV sequence mutations can be detected in plasma or serum specimens, simultaneously [37]. TRUGENE1 HBV Genotyping Assay (RUO). Siemens Medical Solutions Diagnostics, Tarrytown, NY, USA. Information available at: http: //www.medical.-siemens.com (accessed June 2010).

\subsubsection{INNO-LiPA}

A commercially available reverse-hybridization-based line probe assay (INNO LiPA HBV Genotyping assay, LiPA) is easy to perform and is also suitable for detecting mixed genotype infections [38,31]. HBV DNA is amplified by PCR using biotinylated primers complementary to a conserved sequence in the S/pre-S ORF.51. The overall success rate for the detection of all eight HBV genotypes by this method was $98 \%$. INNO-LiPA overestimates mixed infections as a result of erroneous genotype $\mathrm{H}$ detection [39].

\subsubsection{Restriction Fragment Polymorphism (RFLP)}

A PCR-RFLP-based (usually gen $\mathrm{S}$ amplification) method that involves successive digestion of amplicon with a battery of restriction enzymes to discriminate the individual genotypes. It is a simple and cost-effective method which can detect mixed genotypes. It can also determine subgenotypes and can be used in large population studies [40].

\subsubsection{Multiplex PCR}

A multiplex PCR method to identify genotypes using genotype-specific primers in two reactions based on core/surface/polymerase region. Multiplex PCR had a higher accuracy (93.2\%) compared to the RFLP method (87\%). This method can detect mixed genotypes while having sufficient sensitivity for detecting minor species as low as $10 \%[41]$.

\section{Table 1. Commercial Assays for HBV DNA Quantitation}

\begin{tabular}{|c|c|c|}
\hline Methods & Lower Limit of Detection (LLD) & Automation \\
\hline \multicolumn{3}{|l|}{ Hibridizations methods } \\
\hline Branched DNA VERSANT hepatitis B virus DNA 3.0 (Bayer Healthcare LLC, NY, USA) & $3,3 \times 103$ copies $/ \mathrm{mL}$ & \\
\hline \multicolumn{3}{|l|}{ Convencional PCR } \\
\hline \multicolumn{3}{|l|}{ Real Time } \\
\hline Abbott PCR (Abbott, Weisbaden, Germany) & $\begin{array}{l}10 \mathrm{IU} / \mathrm{mL} \text { for } 500 \mathrm{ul} \\
15 \mathrm{IU} / \mathrm{ml} \text { for } 200 \mathrm{ul}\end{array}$ & Automated \\
\hline Smart HBVTM (Cepheid, & & Automated \\
\hline Real Art HBV (Artus GmbH, Hamburg, Germany) & $10.2 \mathrm{IU} / \mathrm{mL}$ & Automated \\
\hline Aptima HBV Quantitative assay (Gen-Probe, San Diego, CA) & \multicolumn{2}{|c|}{ Available in 2012} \\
\hline
\end{tabular}

The lower limits of detection of these systems were established against the WHO international standards for HBV DNA. Probit analysis showed the LLODs of the at $95 \%$ CI. Of these methods, only real-time PCR is able to cover t he wide dynamic range required for quantification of the virus in all stages of infection - 10 to $109 \mathrm{IU} / \mathrm{mL}[7,23,28]$. 
This method may be useful for HBV genotyping in largescale clinical and epidemiological studies. The simplicity and rapidity of this PCR assay may reduce the cost and complexity of recognizing these genotypes. Detection sensitivity for this assay was approximately 100-200 copies $/ \mathrm{mL}$ of blood.

\subsubsection{Serological Subtyping}

In this method, HBV serotypes or subtypes are recognized using antibodies against $\mathrm{HBsAg}$. In an enzyme immunoassay format, they are more cost-effective, easy to perform, and have higher throughput. This method is suitable for large epidemiological studies and population screening [41].

\subsubsection{Genotyping by Mass Spectrometry}

The MassARRAY system based on nucleic acid analysis by matrix-assisted laser desorption ionization time-of-flight mass spectrometry (MALDI-TOF MS) provides an alternative approach to HBV genotyping. The MALDI-TOF MS MassARRAY system is capable of detecting wild-type and mutant alleles and can identify mixes if the minority type is present at $>10 \%$ This technology is less costly and easy to use as it is amenable to automation and has already found application in other disease evaluations [42].

The assay is cost-effective because of its relatively high throughput, and it is approximately half the price of sequencing and is 15 times less expensive than InnoLipa. The assay is rapid, the technology allows the testing of 960 specimens a day without requiring any additional analysis, nor any data interpretation by the operator after the data collection is completed. It provides the opportunity to detect the presence of new sequence variants and automatically adds them to the reference database.

Other studies have reported the use of MALDI-TOF mass spectrometry for the determination of YMDD (tyrosine-methionine-aspartate-aspartate motif) mutations, which are linked to lamivudine drug resistance. In these studies, this method was found to be superior to DNA sequencing since it has a lower detection limit (100 copies $/ \mathrm{ml}$ ) and can also detect mutations in samples containing wild types [42].

\subsubsection{Real-Time PCR}

With the development of real-time PCR, several methods have been developed for HBV quantification and genotyping in a single reaction using real-time PCR with additional melting-curve analyses. In these assays, the first step involves the use of the real-time PCR for quantification whilst the second step involves melting curve analyses for differentiating the HBV genotypes. The melting temperature (Tm) value differs among different genotypes depending on the complement between probe and target, and/or GCcontent, of the hybridization sequence $[43,44]$. The main disadvantage of this method is that it is less able to distinguish between genotypes having close proximity between their Tm values, such as A and C.

A new method has been developed for genotyping which makes use of the TaqMan real-time PCR in a multiplex manner this is to identify all genotypes without the need for
post-PCR steps. In this assay, each sample is processed in four multiplex real-time PCRs, each targeting two or three genotype-specific HBV segments. The assay is easy to use and therefore well-suited for routine application in the modern diagnostic laboratory [45].

The use of an absolute quantitative real-time PCR assay allows one to detect mixed infections of different genotypes. It would be useful to know what the relative concentrations are for genotypes B and C in the mixed infections [46].

Other methods, such as the Oligonucleotide microarray, can determine genotypes A-G. The amplified products are heat-denatured and added to silylated slides, to which genotype-specific probes are immobilized. Fifteen probes were designed, based on phylogenetic tree analysis and the alignment of 228 pre-S region sequences. Following washing and drying, fluorescence signals were captured using a scanner. Currently, DNA-Chip technology is not used routinely in the clinical laboratory although the potential is enormous. Besides the information relating to the HBV genotype, more sequence patterns related to antiviral resistance, or promoter sequence variation, can be located on a single chip. However, it should also be noted that an easyto-use assay for this technology is not yet available and that the number of samples that can be analyzed is limited to between 8 and 12 per day $[47,48]$.

\section{HCV (HEPATITIS C VIRUS)}

Hepatitis $\mathrm{C}$ virus (HCV) infection affects approximately 180 million people worldwide. Between 60 and 85 percent of these patients go on to develop chronic HCV infection and this is a major cause of liver-associated disease all over the world, often developing into liver cirrhosis, hepatic failure and hepatocellular carcinoma [49].

HCV belongs to the Flaviviridae family and its genome sequence contains a positive-strand RNA (with approximately 9600 nucleotides) with an open reading frame (ORF) encoding a polyprotein precursor of approximately 3033 amino acids [50]. The genomic organization of $\mathrm{HCV}$ consists of a $5^{\prime}$ untranslated region (5' UTR) with an internal ribosome entry site, an open frame reading that encodes 10 proteins - a structural region including: the "core", the envelope (E1, E2, p7), 6 nonstructural proteins (NS): NS2, NS3, NS4A, NS4B, NS5A, NS5B and a $3^{\prime}$ untranslated region (3' UTR) [51].

The HCV genome is highly heterogeneous: six HCV genotypes ( 1 to 6 ) have been described along with more than 80 distinct subtypes containing diversity in their worldwide distribution, transmission, severity of liver disease [52] and in their response to interferon/Ribavirin treatment [53]. Noncoding regions are relatively well-conserved but the envelope regions, especially HVR1, have the highest mutation rate [54].

Early diagnosis of active $\mathrm{HCV}$ infection is essential if there is to be any chance of a cure, either spontaneously or by antiviral therapy [55]. The tests available for the diagnosis and monitoring of $\mathrm{HCV}$ infection include indirect tests such as a serological test for antibody detection, or direct tests such as the detection of the core antigen or a molecular test. 


\subsection{Serologic Assays}

The initial screening to investigate suspected $\mathrm{HCV}$ exposure is based on the detection of anti-HCV by the enzyme immunoassay (EIA) or chemiluminescence immunoassay (CLIA) of serum samples - this is because they are reproducible, inexpensive and perfectly automated [56]. Commercial EIA uses a mixture of recombinant proteins and synthetic peptide antigens from different $\mathrm{HCV}$ coding regions captured on microtiter plate wells [57]. Three generations of EIA have been developed in order to improve the sensitivity and specificity in immunocompetent patients [58] by the introduction of new HCV proteins, increasing the reliability of the test and increasing the detection of anti$\mathrm{HCV}$ at an earlier stage [59]. Third-generation commercial EIA uses recombinant NS4 proteins (C100-3), nonstructural regions (NS3 and NS4) with antigens from the core region and an NS5 [60]. The second and third generation assays in blood banks have dramatically reduced the incidence of post transfusion hepatitis [61].

CDC guidelines recommend a specific s/co ratio for each test that would predict a true antibody-positive result $\geq 95 \%$ of the time, regardless of the characteristics of the population being tested; this is to decrease the number of the samples that need a confirmatory test [62]. See Table 2.

Table 2. Main Features of Commercial EIAs (Adapted from Kim et al. J Clin Microbiol 2008; 46: 3919-23

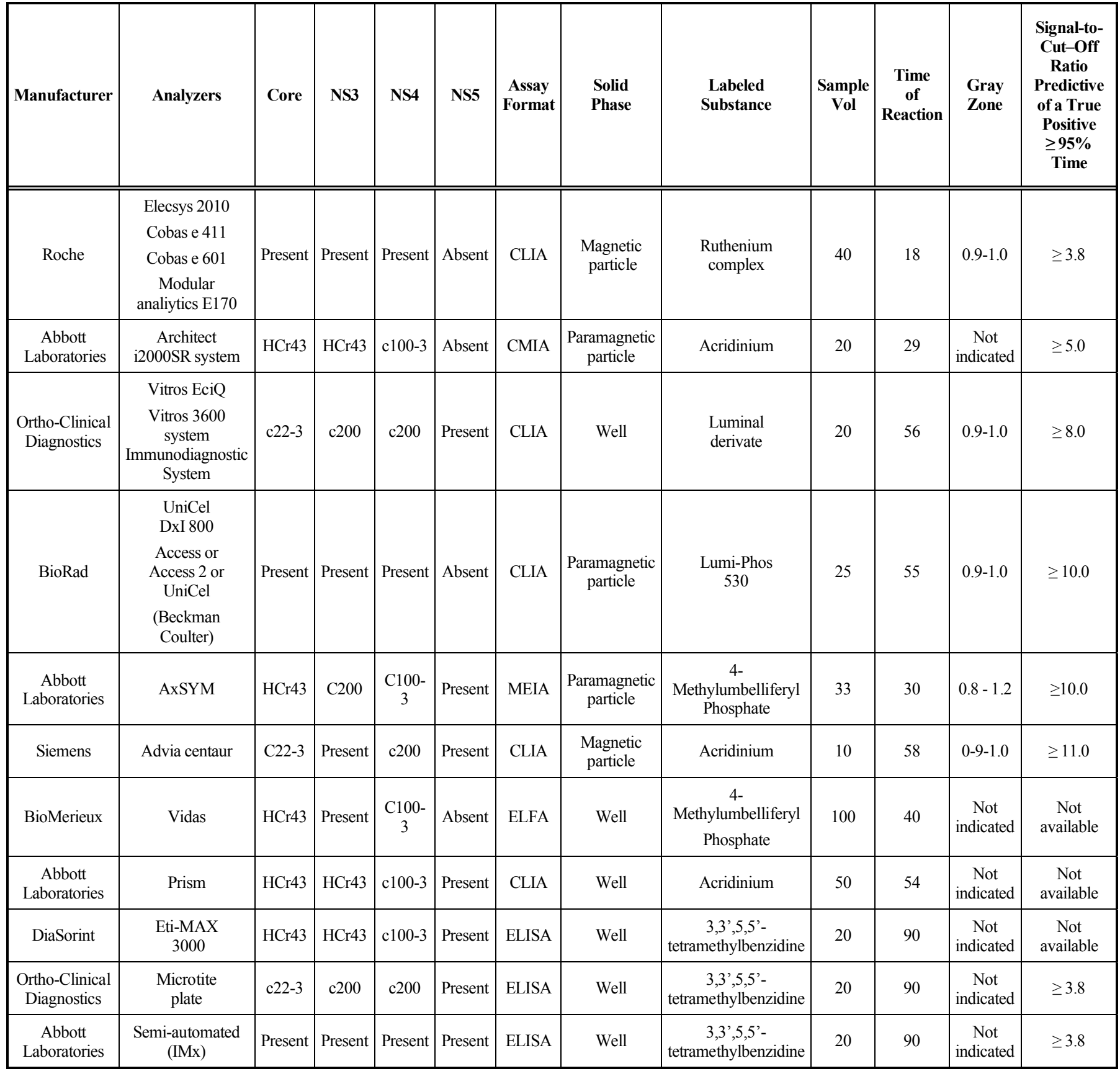

ELISA: Enzyme-linked Immunosorbent Assay; CLIA: Chemiluminescence Immunoassay; MEIA: Microparticle capture Enzyme ImmunoAssay Ortho-Clinical Diagnostics, Buckinghamshire, Germany; Roche Diagnostics GmbH, Mannheim Germany; Abbott Laboratories, Wiesbaden, Germany; Siemens Healthcare Diagnostics, Deerfield, IL; BioMerieux Clinical Diagnostics, France; Bio-Rad, Marnes-la-Coquette, France. 
The limitations of HCV-Abs tests are: 1) In patients with acute $\mathrm{HCV}$ infection, it may remain undetectable for between 45-68 days ("the window period") [56]; 2) The high rate of false positives due to the multiple presence of circulating immunoglobulins [63]; 3) There may be a negative result in patients who are immunocompromised - so a negative result does not rule out exposure or infection. In the general population, and among blood donors, the specificity is lower - thus blood banks use recombinant immunoblot techniques to confirm the EIA results [64].

Automated EIAs for the detection of anti-HCV are widely-used in high-volume clinical laboratories and these instruments offer excellent precision and reliability, as well as high-speed throughput, random access and technical simplicity.

\subsubsection{Supplementary Test (Immunoblot)}

Recombinant immunoblot assays (RIBAs) are used as confirmatory tests when EIA are prone to repeated falsepositive results. Immunoblot assays use artificial HCV proteins, recombinant proteins and/or synthetic peptides that are separately coated on a nitrocellulose strip; except the Murex assay, in which a mixture of 4 recombinant $\mathrm{HCV}$ antigens are electrophoresed on polyacryalmide gel then electrobotted to nitrocellulose. Third-generation RIBA strip assays use two recombinant antigens c33c (NS3) and NS5 and two synthetic peptides c100 (NS4) and 5-1-1 (NS4) derived from putative nonstructural regions of the virus, while the third peptide $\mathrm{c} 22$ corresponds to the nucleocapsid (core) viral protein [65]. Band reactivity is graded by visual calibration against immunoglobulin $\mathrm{G}$ control bands present on each strip. A sample is considered positive when at least two $\mathrm{HCV}$ bands have $1+$ or greater reactivity, considered indeterminate when only a single $\mathrm{HCV}$ band has $1+$ or greater reactivity, whilst considered negative when no HCV bands have $1+$ or greater reactivity [66]. The main disadvantage of RIBA is the occurrence of indeterminate results in problematic samples although some new confirmations of the third-generation RIBA assays have changed the positivity criteria, reducing the frequency of indeterminate results so these are currently being carried out by molecular methods. Five percent of supplementary tests give an indeterminate result in immunocompetent patients, usually because it is in the early stages of the HCV primary infection but it may be greater than $30 \%$ in low-risk populations [67] (Table 3).

\subsubsection{Core Antigen}

The detection of the $\mathrm{HCV}$ core $\mathrm{Ag}(\mathrm{HCVcAg})$ can be used for the detection of HCV infection in the "window period" by a conventional ELISA [68] because it appears in the serum from 1 day before the appearance of HCV RNA, and 45 days sooner than $\mathrm{HCV}$ antibodies [69,70]. It is also more stable after freezing or heating than HCV RNA [71].

Two types of test have been developed: HCV antigens can be detected either as a standalone antigen test or as an antigen/antibody combination test during the "window period", or during active viral replication after the development of antibodies [70,72,73].

Table 3. Epitope Map Tested in the Different Confirmatory Anti-HCV Test ((Modified from E Dussaix, et al. J. Clin. Microbiol. 1994,32(9): 2071-75)

\begin{tabular}{|c|c|c|c|c|c|c|}
\hline Core & E2/NS1 & NS3 & NS4 & NS5 & Reagent & Manufacturer \\
\hline \hline C22 & & C200r & C200 & & Ortho RIBA-2 & Chiron Corporation \\
\hline C1 C2 & & 4091 & NS4 & & Deciscan HCV plus & Sanofi Diagnostics Pasteur \\
\hline C22 & & C33c & C100/5-1-1 & NS5r & Ortho RIBA-3 & Chiron \\
\hline C1 C2 & E2/NS1 & NS3 & NS4 & NS5 & Innolia-III HCV antibody III & Innogenetics NV \\
\hline C22 & & NS3 & NS4 & NS5 & Bioblot HCV 3.0 & Bokit-Izasa \\
\hline
\end{tabular}

Sanofi Diagnostics Pasteur, Marnes-la-Coquette, France; Innogenetics NV, Ghent, Belgium; Ortho Diagnostic Systems, Chiron Corp., Emeryville, California.

Table 4. Main Characteristic of HCVcAg Assays

\begin{tabular}{|c|c|c|c|c|c|c|c|c|c|}
\hline Assay & Detect & $\begin{array}{c}\text { Assay } \\
\text { Format }\end{array}$ & $\begin{array}{l}\text { Solid } \\
\text { Phase }\end{array}$ & $\begin{array}{l}\text { Labelled } \\
\text { Substance }\end{array}$ & $\begin{array}{l}\text { Sample } \\
\text { Vol }(\mu \mathrm{l})\end{array}$ & $\begin{array}{c}\text { Time of } \\
\text { Reaction }\end{array}$ & Pretreatment & $\begin{array}{l}\text { Cut-Off } \\
\text { (fmol/L) }\end{array}$ & Type of EIA \\
\hline $\begin{array}{c}\text { Architect } \\
\text { Anti-HCV } \\
\text { Ag core (Abbott } \\
\text { Laboratories) }\end{array}$ & $\mathrm{Ag} / \mathrm{Ab}$ & CLIA & $\begin{array}{c}\text { Paramagnetic } \\
\text { particle }\end{array}$ & Acridinium & 200 & $37 " \mathrm{~min}$ & Yes & 3.0 & Two step \\
\hline $\begin{array}{c}\text { Murex } \\
\text { HCV-Ag/Ab } \\
\text { (Abbott } \\
\text { Laboratories) }\end{array}$ & $\mathrm{Ag} / \mathrm{Ab}$ & ELISA & Well & $\begin{array}{l}\text { Luminal } \\
\text { derivate } \\
\text { (TMB) }\end{array}$ & 50 & $180 \mathrm{~min}$ & Yes & $\begin{array}{l}\text { Mean } \\
\text { (Negative } \\
\text { control) } \\
+0.2\end{array}$ & $\begin{array}{l}\text { Two-step } \\
\text { sandwich }\end{array}$ \\
\hline $\begin{array}{c}\text { Monolisa HCV } \\
\text { Ag/Ab ULTRA } \\
\text { (Bio-Rad } \\
\text { Laboratories) }\end{array}$ & $\mathrm{Ag} / \mathrm{Ab}$ & ELISA & Well & $\begin{array}{l}\text { Estreptavidina- } \\
\text { peroxidasa }\end{array}$ & 50 & $160 \mathrm{~min}$ & No & $\begin{array}{c}\text { Mean } \\
\text { (Positive } \\
\text { control/4) }\end{array}$ & $\begin{array}{c}\text { Indirect test } \\
(\mathrm{Ab}) \text { and } \\
\text { sandwich test } \\
(\mathrm{Ag})\end{array}$ \\
\hline
\end{tabular}


Table 5. Commercial Qualitative and Quantitative HCV Molecular Assays (Modified from Ghani et al. Hepatology 2009)

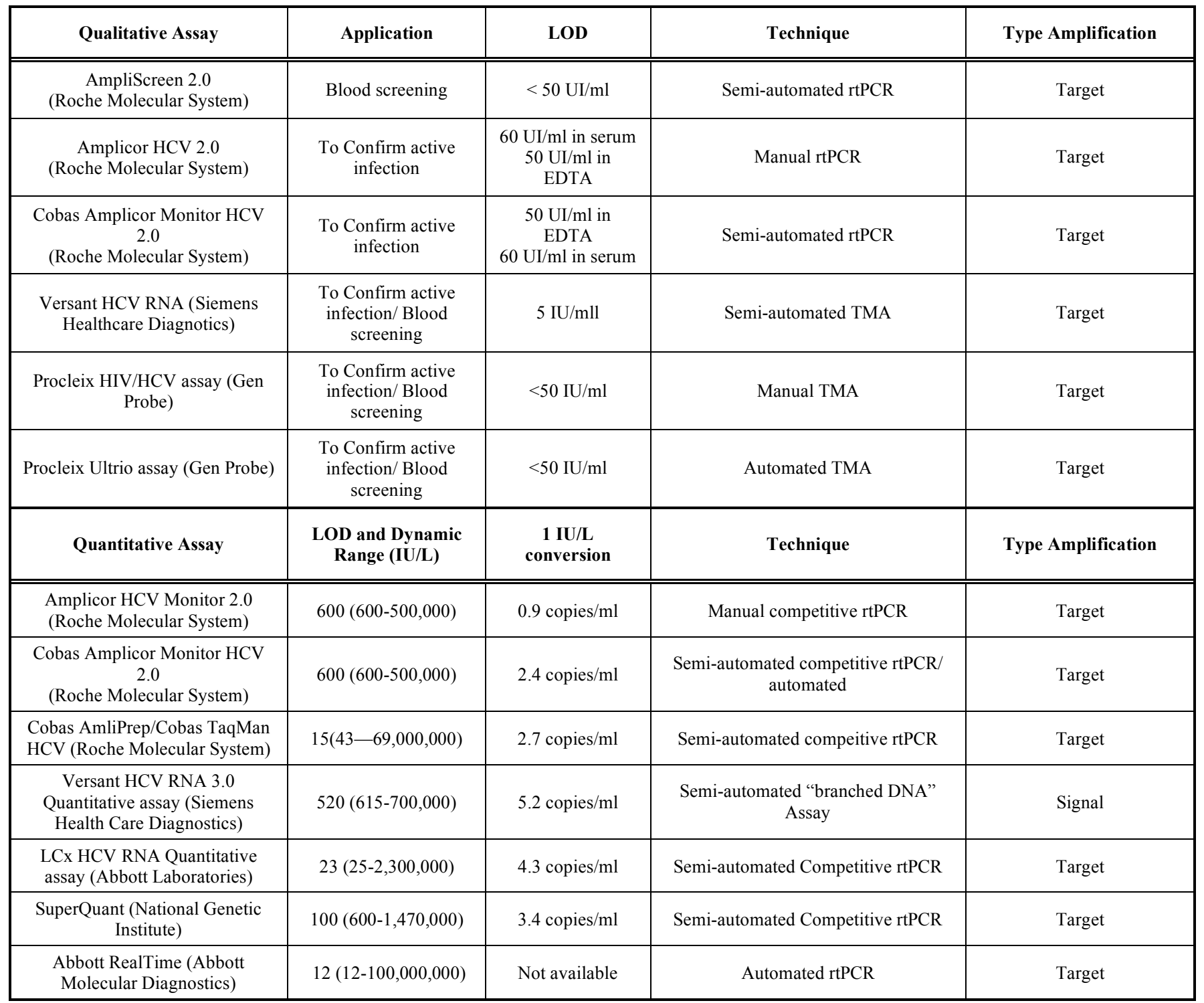

Second generation $\mathrm{HCV} c \mathrm{Ag}$ assays have reduced the pretreatment steps and improved sensitivity by more than a $100-$ fold [74] - this has been done by adding detergents to dissociate $\mathrm{HCV} \mathrm{Ag}-\mathrm{Ab}$ complexes, and by the addition of four antibodies against highly-conserved regions $[75,76]$.

Some reports recommend that $\mathrm{HCV} \mathrm{cAg}$ assays could be a cost-effective alternative compared to RT-PCR when used to: demonstrate HCV replication [68]; diagnose acute infection in immunocompetent patients, or patients with severe immunosupression (HIV infection; hemodialyzed patients etc..) except for hemodyalisis patients with lowlevel viremia [77,78]; evaluate chronic infection and monitor the response to antiviral therapy with comparable results to those of HCV-RNA PCR $[68,77]$. Furthermore, they do not require specialized equipment or skilled personnel, and are less expensive - taking less than an hour to develop. However, the major limitation is the lower limit of detection (LLOD), which in the new-generation of commercial assays is $10^{3} \mathrm{IU} / \mathrm{mL}$ of viral RNA. Therefore, $\mathrm{HCVcAg}$ is less sensitive than HCV-RNA assays when used in treatment monitoring or response-guided therapy [68] because false negatives of these kits range to 7-10\% [69].

Quantitative $\mathrm{HCV}$ cAg titer was correlated with the $\mathrm{HCV}$ RNA level and found that the sensitivity and specificity of different genotypes can vary but this discrepancy is minimal [68]. The threshold recommended at the International Consensus Conference on Hepatitis $\mathrm{C}$ for predicting the outcome of treatment was that $800,000 \mathrm{IU} / \mathrm{ml}$ of HCV RNA correspond to $32 \mathrm{pg} / \mathrm{ml}$ of $\mathrm{HCVcAg}$ [78].

An early $\mathrm{HCV} c \mathrm{Ag}$ decrease down to undetectable levels within four weeks may be predictive of a sustained virologic response (SVR) after commencing combination therapy, and a detectable $\mathrm{HCV} \mathrm{cAg}$ at 12 weeks has a positive predictive value of $100 \%$ for non-SVR $[77,79]$.

The Architect HCVcAg assay, performed on the Architect i2000SR CLIA analyzer, has a detection limit of $3 \mathrm{fm} / \mathrm{L}$, or 0.06 $\mathrm{pg} / \mathrm{ml}$ of recombinant $\mathrm{c} 11 \mathrm{Ag}$ (residues 1-160) of the isolated HCV genotype 2a and a dynamic range extended to 180,000 $\mathrm{fmol} / \mathrm{L}$ with an automated 1: 9 dilution. The total assay time is $40 \min [80]$. 


\subsection{Molecular HCV Assays}

Molecular assays are crucial for the management (detection and quantification) of $\mathrm{HCV}$ infected patients because RNA can be detected 10-14 days after infection and approximately 1 month before the appearance of antibodies [81].

To standardize automatic molecular assays, WHO has developed an HCV RNA international standard based on international units $(\mathrm{IU} / \mathrm{mL})$, which has facilitated the interpretation of the viral load values of different methods. The first standard (96/790) was developed in 1997 and the second standard (96/798) was performed in 2003 with an assignation of $10^{5} \mathrm{IU} / \mathrm{ml}$. Commercial assays are calibrated through the WHO standard based on HCV genotype 1 [82]. The assays must detect all genotypes, regardless of the viral load level.

LLOQ is accurate and reproducible because it is within the dynamic range of quantification, whereas the LLOD is defined statistically, and the actual amount of HCV RNA it indicates varies among patients and samples. Therefore, the LLOD is not suitable for making individual therapeutic decisions. Future assays should have identical LLOD and LLOQ values to ensure accurate definition of undetectable levels of HCV RNA. In the meantime, new time points should be defined for accurate assessment using the LLOQ [83]. The LLOD required for the quantitative test is 50 $\mathrm{IU} / \mathrm{mL}$, but for the new real-time quantitative assays, it is 15 $\mathrm{IU} / \mathrm{mL}$ with a large linear range (LR) of HCV RNA detection: $50 \mathrm{IU} / \mathrm{mL}$ to 6 or $7 \log \mathrm{IU} / \mathrm{mL}$ [84] (Table 4).

Quantitative and qualitative HCV RNA assays are based on: amplification of the target [transcription-mediated amplification (TMA), classical reverse-transcription polymerase chain reaction and real-time (RT-PCR)] or amplification of the signal (branched DNA, bDNA) [84,85] (Table 5).

\subsubsection{Qualitative HCV RNA (RNA Detection)}

Qualitative assays detect viral genomes and are used to define active infection and to confirm EIA results (diagnosis and monitoring) as well as for the screening of blood donors.

\subsubsection{Polymerase Chain Reaction (PCR-Based Assays)}

The COBAS $^{\circledR}$ Amplicor HCV Test v2.0 is performed on the COBAS $^{\circledR}$ AMPLICOR Analyzer (Roche Molecular systems). HCV RNA is isolated from virions by lysis of viral particles and alcohol precipitation. An RNA script with primer binding identical regions to those of the HCV target is introduced into each sample and serves as an internal control. The test utilizes reverse transcription of target RNA to generate complementary DNA (cDNA), which is denatured by heating, and then the target cDNA is amplified by the Polymerase Chain Reaction (PCR) and nucleic acid is hybridized for the detection of HCV RNA in human serum or plasma. In the last phase, a coloured complex is formed, which is measured at $660 \mathrm{~nm}$ [86].

Transcription-mediated amplification (TMA) is an isothermal nucleic acid amplification process that involves a more complex set of reactions with the reverse transcriptase and T7 RNA polymerase.
The Versant HCV RNA Qualitative Assay (Siemens Molecular): In this method, sample preparation, target amplification and amplicon detection are carried out in a single tube. Following a lysis step, target HCV RNA is captured by magnetic particles coated with oligonucleotides complementary to the $5^{\prime}$ UTR of the HCV genome. Monitoring of target capture and amplification is achieved by adding an internal control RNA to each sample. The target RNA is then amplified with an isothermal TMA process that requires the addition of primers, reverse transcriptase, and T7 RNA polymerase. Some of the newly synthesized RNA amplification products re-enter the TMA process and serve as templates for new rounds of amplification. To detect the amplified product, TMAlabelled oligonucleotide probes are used to emit a chemiluminescent signal [86]. The LLOD is $5 \mathrm{IU} / \mathrm{ml}$ and 10 $\mathrm{IU} / \mathrm{ml}$ with a sensitivity from $96 \%$ to $100 \%$, respectively. It is independent of HCV genotypes $[86,87]$ and may be useful in predicting which patients are at risk from virological release after cessation of antiviral therapy, helping to define treatment response and determine acute infection [88].

\subsubsection{Quantitative HCV RNA}

These methods for accurate quantification of HCV RNA levels have become key tools in the clinical management of patients under treatment and to predict the response probability to combination interferon/ribavirin therapy by assessing rates of HCV viral load decline as well as to complement the information provided by $\mathrm{HCV}$ genotype determination. Finally, HCV viral kinetics data are essential for the understanding of new therapeutics such as the protease class of inhibitors [89].

\subsubsection{Target Amplification Techniques by Reverse Transcriptase-Polymerase Chain Reaction (RT-PCR)}

In real-time PCR monitors, the fluorescence emitted during amplification can be detected during the enzymatic reaction in each PCR cycle. This differs from end-point PCR by using fluorogenic probes, primers, and amplicons. Quantitative measurements occur during the exponential phase of the amplification step; the quantity of the amplification products is proportional to the quantity of the $\mathrm{HCV}$ or internal standard initially present in the sample. These assays have a broad dynamic range, improving LLOD $\leq 10 \mathrm{IU} / \mathrm{mL}$ without the need for pre-dilution in addition to being specific, accurate and reproducible. The most common assays available for fluorescence detection include: hydrolysis probe assays, hybridization probes such as molecular beacons, dual-hybridization probes, scorpion primers and DNA binding dyes (SYBR green) $[85,90]$. There are two commercial quantitative real-time PCRs for $\mathrm{HCV}$ RNA:

The Abbott Real Time HCV assay (Abbott Laboratories, IL., USA) is performed on the m2000sp for sample extraction and m2000rt for amplification-quantitative processing.

The Cobas AmpliPrep/Cobas TaqMan HCV Test (Roche Molecular Systems) is integrated into the fully automated Docking Station $^{\circledR}$ modular platform. It is a probe-based method, which combines automated isolation on the COBAS AmpliPrep $^{\mathrm{TM}}$ followed by amplification-quantitative detection on the COBAS Taqman 48/96 Analyzer $^{\mathrm{TM}}$ [91]. 
Reverse transcription and amplification primers, as well as the probe, are targeted to the HCV 5'UTR of HCV. In each complete process, a quantitative standard is included to compensate for the inhibition effects and for process control. It has an LLOD and high performance but there are two critical points: sample overestimation with high viral loads and viral load underestimation for genotype 2 and 4 [92].

LightCycler (Biorad, CA, USA) uses hybridization probes and SYBR Green (Molecular Probe Inc) uses DNAbinding agents. SYBR Green I, however, has a number of limitations that include the inhibition of PCR, preferential binding to GC-rich sequences and effects on melting curve analysis [93].

The AMPLICOR HCV MONITOR Test v2.0 (Roche Molecular Systems) is available on the COBAS AMPLICOR $^{\circledR} \quad$ Analyzer, which allows automated amplification, detection, and reporting for HCV RNA quantification. The primers allow RT-PCR of the 5'UTR region of the HCV genome. On the COBAS AMPLICOR Analyzer, thermal cycling and detection is carried out via a colorimetric format using suspensions of magnetic particles coated with probes specific for the HCV and QS amplicons. Absorbance measurements are made using the COBAS AMPLICOR. Although it is highly reproducible, it has low sensitivity and yield [94].

\subsubsection{Signal Amplification Techniques by Branched DNA (bDNA)-Based Assays}

The risk of contamination is reduced by the elimination of target nucleic acid amplification. The target nucleic acid is immobilized to a support thus allowing different washes to take place so that false-positive results are kept to a minimum [95].

The most used is the Versant 3.0 Quantitative assay performed by the System 340 bDNA Analyzer (Siemens Medical Solutions Diagnostics). This is a semi-automated RNA test to quantify $\mathrm{HCV}$, which uses a solid-phase oligonucleotide probe to capture the target RNA, followed by hybridization of a branched secondary (bDNA) probe. The capture probes and the target probes bind to the 5'UTR and core regions. The DNA amplifiers bind to enzymeconjugated tertiary probes, and after substrate is added, the chemiluminescence produced is proportional to the amount of target RNA [96]. Currently, Siemens have released the VERSANT ${ }^{T M} 440$ Molecular Systems, a fully automated system [97].

\subsubsection{Genotype Test}

Knowing the infecting genotype has a direct impact on the prognosis and on the choice and duration of the treatment algorithm as well as being a statistically significant predictor of SVR to antiviral therapy [98].

The reference method for $\mathrm{HCV}$ molecular typing is genome sequencing and subsequent phylogenetic analysis but this method cannot be used in Clinical laboratories. Most of the commercial genotyping methods are based on the detection of the 5'UTR region, which is amplified easily and has enough polymorphism to distinguish between different genotypes. The NS5B region is amplified with difficulty, mainly genotype 4 [99]. The serological method has lower sensitivity and specificity than molecular assays [100].
Firstly, in these assays, the subgenomic region is amplified, determined by chain reaction polymerase in real time (RT-PCR), after which the different types are discriminated by direct sequencing [101] (TRUGENE HCV 5 ' $\mathrm{NC}$ region genotyping assay; Visible Genetics, Canada), followed by reamplification with genotype-specific primers or subtype [102]; reverse hybridization of amplicons with immobilized membrane (INNO-LiPA HCV I/II/ VERSANT $\mathrm{HCV}$ genotype assay 2.0; Innogenetics, N.V./Siemens Medical Solutions Healthcare) with either genotype-specific probes or subtype [103]; RFLP (restriction fragment length polymorphism DNA) [104]; heteroduplex mobility analysis using capillary electrophoresis gradient temperature [105] or dissociation curve analysis using fluorescent probes FRET technology (fluorescence energy transfer resonance) [106].

\subsubsection{Direct Nucleic Acid Sequencing}

The product amplified in the TRUGENE $^{\circledR}$ assay is neutralized, purified and subsequently sequenced in both directions by a capillary method (ClipTM). The obtained sequence is aligned with prototypical sequences of different genotypes and subtypes and then a computer program performs a phylogenetic analysis to determine genotype and subtype [107].

\subsubsection{DNA Hybridization}

INNOLIPA HCV II is based on reverse hybridization and uses PCR products from the 5'UTR, after being denatured, it is subjected to hybridization with multiple probes and two control targets aligned and fixed to the nitrocellulose membrane by means of respective poly-(T) queues. The hybrids formed are evidenced by the addition of a conjugate (streptavidin-labelled alkaline phosphatase) followed by chromogenic substrate. The genotype is determined after alignment with the card strip test reference. LiPA II includes 22 probes of different genotypes and subtypes [108].

TRUGENE $^{\circledR}$ and INNO-LIPA assays can be performed with amplification products obtained from Roche AMPLICOR assays. Some reports have indicated that the two assays have similar abilities in determining genotypes (rates from $95-100 \%$ ) but that the main limitation is the difficulty in accurately defining some subtypes of $\mathrm{HCV}$ strains [107].

The Invader HCV Genotyping Assay (Third Wave Technologies, Inc., Madison, Wisconsin) is based on the analysis of the 5'UTR, using DNA cleavase technology and FRET. The amplicons may be generated from different commercial methods. It can be completed in $1.5 \mathrm{~h}$ (after amplification) and is precise with genotypes yet imprecise with subtypes [109].

\subsubsection{Restriction Fragment-Length Polymorphism (RFLP)}

These use universal primers that are subjected to nested PCR followed by digestion of the amplicon with restriction enzymes at the genotype-specific site [110].

Other commercial assays are based on the analysis of subgenomic regions: such as the core region (GEN-ETI-K DEIA kit, Sorin, Italy) or the NS5B region (NS5B Genotyping Assay TRUGENE, Siemens Medical Solutions) or 5'UTR and core regions (VERSANT 2.0, Siemens). These have improved the discrimination between subtypes or the 
Abbott Real Time HCV Genotype ${ }^{\circledR}$ (Abbott Molecular Diagnostics), where the RNA is purified from plasma and amplified using specific primers of the NS5B regions, 5'UTR and a recombinant thermostable polymerase with transcriptase and DNA polymerase activity. The cycles of amplification are realized on the ABI PRISM ${ }^{\mathbb{B}} 7000$ and the data obtained are analyzed using the Sequence Genotyping Software Program 2.0 (Celera Diagnostics, Alameda, California). The LOD is $1,200-1,500 \mathrm{U} / \mathrm{ml}$. It does not accurately discriminate between genotypes 4 and 6 [111].

\subsubsection{Primer-Specific \& Mispair Extension Analysis}

The PSMEA HCV genotyping test detects genotypespecific sequence differences in the 5'UTR and is considered to be a high throughput rapid genotyping assay that can reliably identify mixed HCV infections [112].

Liquid microarrays are used for HCV genotyping and are based on the analysis of the 5'UTR and NS5B regions. The xMap Technology (Luminex Corp, Austin, Texas) is based on short pieces of DNA attached to tiny plastic beads, or microspheres, floating in a sample. It is similar to a gene chip, where many nucleic acid sequences can be detected simultaneously with a LLOD of 50 copies/reaction [113].

\subsubsection{Nanoparticles}

Nanoparticles have been proposed as promising tools to develop the next generation of assays. The most common nanoparticles used are: quantum dots and gold nanoparticles (AuNPS).

AuNPS are spheres with a typical diameter of $2-50 \mathrm{~nm}$ and have the property known as "surface plasmon resonance": when the particles are distributed evenly throughout a liquid, they reflect light in a way that makes them appear red; when they clump together, they look blue $[114,115]$. The RNA is extracted from the virion and then short pieces of DNA complementary to the HCV RNA and the gold nanoparticles are added to this solution. In the absence of HCV RNA, the primers stick to the gold nanoparticles and separate them, thus the solution appears red. If the virus is present, the primers pair with the viral RNA instead and the gold nanoparticles aggregate, turning the solution blue. The test is performed in a tube and takes only 30 minutes [115].

\section{CONCLUSIONS}

Today, fully-automated platforms are available for the detection of serological and molecular markers of HBV and $\mathrm{HCV}$ infection. New enzyme immunoassays can quantify hepatitis B surface and hepatitis C core antigens, which can then be used for prognosis and treatment monitoring. Over the next few years, it is expected that tests will be developed for the detection of $\mathrm{HCV}$ which are based on multianalyte micro-fluidic chips, nucleic acid lateral-flow and point-ofcare tests, which will improve the management of $\mathrm{HCV}$ infected patients.

The currently available real-time PCR are simple to perform and have a short turnaround time. In addition, they have a large LR, minimal contamination risk and can be combined with automated DNA-HBV and RNA_HCV extraction to provide an excellent platform for the detection and quantification of $\mathrm{HCV}$.
ABBREVIATIONS
AASLD
$=$ American Association for the Study of Liver Diseases guidelines
AuNPS
nanoparticles
$=$ Quantum dots and gold
bDNA
cccDNA
CLIA
ClipTM
FRET
HBV
$\mathrm{HCV}$
HBsAg
qHBsAg
HbcrAg
$\mathrm{HCV} c \mathrm{Ag}$
IS
INNO LiPA
LLOD
LLOQ
LR
$=$ Branched DNA assay
$=$ Co-valently closed circular DNA
$=$ Automated chemiluminescence immunoassay
$=$ Capillary method
$=$ Fluorescence energy transfer resonance
$=$ Hepatitis $\mathrm{B}$ virus
$=$ Hepatitis $\mathrm{C}$ virus
$=$ Hepatitis $\mathrm{B}$ surface antigen
$=$ Quantitative HBsAg
$=\mathrm{HBV}$ core antigen
$=\mathrm{HCV}$ core $\mathrm{Ag}$
$=$ Internal standard
$=$ Reverse-hybridization-based line probe assay
$=$ Lower limit of detection
$=$ Lower limit of quantitation
$=$ Large linear range
MALDI-TOF MS = Mass spectrometry
OFR
$=$ Overlapping reading frames
PSMEA
RFLP
$=$ Primer_specific\& mispair extension analysis
$=$ Restriction fragment length polymorphism
RT-PCR
$=\underset{\text { time }}{\text { Chain reaction polymerase in real }}$
$=$ Recombinant immunoblot assays
$\begin{array}{ll}\text { RIBAs } & =\text { Recombinant immun } \\ \mathrm{Tm} & =\text { Melting temperature }\end{array}$
TMA
$=$ Transcription-mediated amplification
WHO

\section{CONFLICT OF INTEREST}

The author declares that they have no competing interests.

\section{ACKNOWLEDGEMENTS}

Declared none.

\section{REFERENCES}

[1] Lee WM. Hepatitis B virus infection. N Engl J Med 1997; 337 : 1733-45.

[2] Hoofnagle JH, Doo E, Liang TJ, Fleischer R, Lok AS. Management of hepatitis B: summary of a clinical research workshop. Hepatology 2007; 45: 1056-75. 
[3] Lavanchy D. Hepatitis B virus epidemiology, disease burden, treatment, arid current and emerging prevention and control measures. J Viral Hepat 2004; 11(2): 97-107.

[4] Paterson R. Screening immigrants for infectious diseases. Lancet Infect Dis 2003; 3(11): 681

[5] Scotto G, Martinelli D, Di Tullio R, Fazio V. Epidemiological and clinical features of hepatitis B virus genotypes among immigrants in southern Italy hepatitis research and treatment. Hepat Res Treat 2010; 2010: 878356.

[6] Mutimer DJ, Ye HO. Virology Hepatitis. Infect Dis Clin North Am 2006; 20: 47-61.

[7] Servoss JC, Friedman LS. Serologic and molecular diagnosis of hepatitis B. Infect Dis Clin North Am 2006; 20(1): 47-61.

[8] Ismail N, Fish GE, Smith MB. Laboratory evaluation of a fully automated chemiluminescence immunoassay for rapid detection of $\mathrm{HBsAg}$, antibodies to hbsag, and antibodies to hepatitis $\mathrm{C}$ virus. $\mathrm{J}$ Clin Microbiol 2004; 42(2): 610-7.

[9] Weber B, Bayer A, Kirch P, Schlüter V, Schlieper D, Melchior W. Improved Detection of Hepatitis B Virus Surface Antigen by a New Rapid Automated Assay. J Clin Microbiol 1999; 37(8): 263947

[10] Jia JD, Hong M, Wei L, et al. Multicentre evaluation of the Elecsys $^{\circledR}$ hepatitis B surface antigen II assay for detection of HBsAg in comparison with other commercially available assays Med Microbiol Immunol 2009; 198: 263-9

[11] Mühlbacher A, Weber B, Bürgisser P, et al. Multicenter study of a new fully automated $\mathrm{HBsAg}$ screening assay with enhanced sensitivity for the detection of HBV mutants. Med Microbiol Immunol 2008; 197: 55-64

[12] El Chaar M, Candotti D, Crowther RA, Allain JP. Impact of Hepatitis B virus surface protein mutations on the diagnosis of occult Hepatitis B virus Infection. Hepatology 2010; 52(5): 160010 .

[13] Avellon A, Echevarria JM, Weber B, et al. European collaborative evaluation of the enzygnost $\mathrm{HBsAg} 6.0$ assay: performance on hepatitis B virus surface antigen variants. J Med Virol 2011; 83: 95-100.

[14] Lee JM, Ahn SH. Quantification of HBsAg: basic virology for clinical practice. World J Gastroenterol 2011; 17(3): 283-9

[15] Park Y, Hong DJ, Shin S, Cho Y, Kim HS. Performance evaluation of new automated hepatitis B viral markers in the clinical laboratory: two quantitative hepatitis B surface antigen assays and an HBV core-related antigen assay. Am J Clin Pathol 2012; 137(5): 770-7.

[16] Tuaillon E, Mondain AM, Nagot N, et al. Comparison of serum HBsAg quantitation by four immunoassays, and relationships of HBsAg level with HBV replication and HBV genotypes. PLoS One 2012; 7(3): e32143.

[17] Deguchi M, Yamashita N, Kagita M, et al. Quantitation of hepatitis $\mathrm{B}$ surface antigen by an automated chemiluminescent microparticle immunoassay. J Virol Methods 2004; 115: 217-22.

[18] Valsamakis Alexandra. Molecular testing in the diagnosis and management of chronic hepatitis B. Clin Microbiol Rev 2007; 20(3): 426-39.

[19] Berger A, Preiser W, Doerr HW. The role of viral load determination for the management of human immunodeficiency virus. hepatitis B virus and hepatitis $\mathrm{C}$ virus infection. J Clin Virol 2001; 20: 23-30.

[20] Lok AS, Zoulim F, Locarnini S, et al. Hepatitis B Virus Drug Resistance Working Group. Antiviral drug-resistant HBV: standardization of nomenclature and assays and recommendations for management. Hepatology 2007; 46(1): 254-65.

[21] Pawlotsky JM, Dusheiko G, Hatzakis A, et al. Virologic monitoring of hepatitis B virus therapy in clinical trials and practice: recommendations for a standardized approach. Gastroenterology 2008; 134(2): 405-15.

[22] Lok AS, McMahon BJ. Chronic hepatitis B: update 2009. Hepatology 2009; 50(3): 661-2

[23] Vivekanandan P, Singh OV. Molecular methods in the diagnosis and management of chronic hepatitis B. Expert Rev Mol Diagn 2010; 10(7): 921-35.

[24] Ho SK, Chan TM, Cheng IK, Lai KN. Comparison of the secondgeneration digene hybrid capture assay with the branched-DNA assay for measurement of hepatitis B virus DNA in serum. J Clin Microbiol 1999; 37: 2461-5.
[25] Yao JD, Beld MG, Oon LL, et al. Multicenter evaluation of the VERSANT hepatitis B virus DNA 3.0 assay. J Clin Microbiol 2004; 42(2): 800-6.

[26] Kessler HH, Pierer K, Dragon E, et al. Evaluation of a new assay for HBV DNA quantitation in patients with chronic hepatitis B. Clin Diagn Virol 1998; 9(1): 37-43.

[27] Caliendo AM, Valsamakis A, Bremer JW, et al. Multilaboratory evaluation of real-time PCR tests for hepatitis B virus DNA quantification. J Clin Microbiol 2011; 49(8): 2854-8.

[28] Pyne MT, Vest L, Clement J, et al. Comparison of three Roche hepatitis B virus viral load assay formats. J Clin Microbiol 2012; 50(7): 2337

[29] Paraskevis D, Beloukas A, Haida C, et al. Development of a new ultra sensitive real-time PCR assay (ultra sensitive RTQ-PCR) for the quantification of HBV-DNA. Virol J 2010; $7: 57$

[30] Lin CL, Kao JH. The clinical implications of hepatitis B virus genotype: Recent advances. J Gastroenterol Hepatol 2011; 26 (1): 123-30

[31] Guirgis BS, Abbas RO, Azzazy HM. Hepatitis B virus genotyping: current methods and clinical implications. Int J Infect Dis 2010; 14(11): e941-53.

[32] Bartholomeusz A, Schaefer S. Hepatitis B virus genotypes: comparison of genotyping methods. Rev Med Virol 2004; 14: 3-16.

[33] Halfon P, Pol S, Bourlière M, Cacoub P. Hepatitis B virus genotypes: clinical, epidemiological and therapeutic implications. Gastroenterol Clin Biol 2002; 26(11): 1005-12.

[34] Norder H, Couroucé AM, Magnius LO. Complete genomes, phylogenetic relatedness, and structural proteins of six strains of the hepatitis B virus, four of which represent two new genotypes. Virology 1994; 198(2): 489-503

[35] Okamoto H, Tsuda F, Sakugawa H, et al. Typing hepatitis B virus by homology in nucleotide sequence: comparison of surface antigen subtypes. J Gen Virol 1988; 69: 2575-83.

[36] Norder H, Couroucé AM, Coursaget $\mathrm{P}$, et al. Genetic diversity of hepatitis B virus strains derived worldwide: genotypes, subgenotypes, and HBsAg subtypes. Intervirology 2004; 47(6): 289-309.

[37] TRUGENE1 HBV Genotyping Assay (RUO). Siemens Medical Solutions Diagnostics, Tarrytown, NY, USA. Information available at: http: //www.medical.-siemens.com [Accessed June 2010].

[38] Qutub MO, Germer JJ, Rebers SP, Mandrekar JN, Beld MG, Yao JD. Simplified PCR protocols for inno-lipa HVB genotyping and inno-lipa HBV precore assays. J Clin Virol 2006; 37(3): 218-21.

[39] Ali MM, Hasan F, Ahmad S, Al-Nakib W. Comparative evaluation of INNO-LiPA HBV assay, direct DNA sequencing and subtractive PCR-RFLP for genotyping of clinical HBV isolates. Virol J 2010; 7: 111.

[40] Laperche S, Girault A, Beaulieu MJ, Bouchardeau F, Courouce AM. Determination of hepatitis B virus subtypes by an enzyme immunoassay method using monoclonal antibodies to type-specific epitopes of HbsAg. J Viral Hepat 2001; 8: 447-53.

[41] Gintowt AA, Germer JJ, Mitchell PS, Yao JD. Evaluation of the MagNA Pure LC used with the TRUGENE HBV Genotyping Kit. J Clin Virol 2005; 34(2): 155-7.

[42] Ganova-Raeva L, Ramachandran S, Honisch C, Forbi JC, Zhai X, Khudyakov Y. Robust hepatitis B virus genotyping by mass spectrometry. J Clin Microbiol 2010; 48(11): 4161-8

[43] Hong SP, Kim NK, Hwang SG, et al. Detection of hepatitis B virus YMDD variants using mass spectrometric analysis of oligonucleotide fragments. J Hepatol 2004; 40(5): 837-44.

[44] Payungporn S, Tangkijvanich P, Jantaradsamee P, Theamboonlers A, Poovorawan Y. Simultaneous quantitation and genotyping of hepatitis B virus by real-time PCR and melting curve analysis. J Virol Methods 2004; 120(2): 131-40.

[45] Sitnik R, Paes A, Mangueira CP, Pinho JR. A real-time quantitative assay for hepatitis B DNA virus (HBV) developed to detect all HBV genotypes. Rev Inst Med Trop Sao Paulo 2010; 52(3): 11924.

[46] Malmström S, Berglin-Enquist I, Lindh M. Novel Method for Genotyping Hepatitis B Virus on the Basis of TaqMan Real-Time PCR. J Clin Microbiol 2010; 48(4): 1105-11.

[47] Wang YZ, Xiao JH, Liu LG, et al. Simultaneous detection of hepatitis $\mathrm{B}$ virus genotypes and mutations associated with resistance to lamivudine, adefovir, and telbivudine by the polymerase chain reaction-ligase detection reaction. Braz J Infect Dis 2011; 15(6): 560-6. 
[48] Pas SD, Tran N, de Man RA, Burghoorn-Maas C, Vernet G, Niesters HG. Comparison of reverse hybridization, microarray, and sequence analysis for genotyping Hepatitis B. J Clin Microbiol 2008; 46(4): 1268-73.

[49] Davis GL, Albright JE, Cook SF, Rosenberg DM. Projecting future complications of chronic hepatitis $\mathrm{C}$ in the United States. Liver Transpl 2003; 9: 331-8.

[50] Hugo R, Rosen MD. Chronic hepatitis C infection. N Engl J Med 2011; 364: 2429-2438.

[51] Chevaliez S, Pawlotsky JM. Hepatitis C Viruses: Genomes and Molecular Biology. Tan SL, Ed. Norfolk (UK): Horizon Bioscience 2006.

[52] Gottwein JM, Scheel TK, Jensen TB, et al. Development and characterization of hepatitis $\mathrm{C}$ virus genotype 1-7 cell culture systems: role of CD81 and scavenger receptor class B type I and effect of antiviral drugs. Hepatology 2009; 49: 364-77.

[53] Kuiken C, Saimonds P. Nomenclature and numbering of the hepatitis C virus. Methods Mol Biol 2009; 510: 33-53.

[54] Smith DB, Mellor J, Jarvis LM, et al. Variation of the hepatitis C 5 ' non-coding region: implications for secundary structure, virus detection and typing. The International HCV Collaborative Study Group. J Gen Virol 1995; 76(Pt 7): 1749-61.

[55] Yu ML, Chuang WL. Treatment of chronic hepatitis C in Asia: when East meets West. J Gastroenterol Hepatol 2009; 24: 336-45.

[56] Kesli R, Polat H, Terzi Y, Kurtoglu MG, Uyar Y. Comparison of a newly-developed automated and quantitative hepatitis $\mathrm{C}$ virus (HCV) core antigen test with the HCV RNA assay for Clinical usefulness in confirming anti-HCV results. J Clini Microbiol 2011; 4089-93.

[57] Chevaliez S, Pawlotsky JM. Use of virologic assays in the diagnosis and management of hepatitis $\mathrm{C}$ virus infection. Clin Liver Dis 2005; 9: $371-82$.

[58] Prats G. Pruebas inmunológicas. Microbiología clínica. Ed Panam 2005; 8: 157-87.

[59] Alborino F, Burighel A, Tiller FW, et al. Multicenter evaluation of a fully automated third-generation anti-HCV antibody screening test with excellent sensitivity and specificity. Med Microbiol Immunol 2011; 200(2): 77-83.

[60] Colin C, Lanoir D, Touzet S, et al. and the Hepatitis Group. Sensitivity and specificity of third-generation hepatitis $\mathrm{C}$ virus antibody detection assays: an analysis of the literature. J Viral Hepat 2001; 8: 87-95

[61] Dow BC, Follett EA, Jordan T, et al. Testing of blood donations for hepatitis C virus (letter). Lancet 1994; 343: 477-8.

[62] Alter MJ, Kuhnert WL, Finelli L. Guidelines for laboratory testing and result reporting of antibody to hepatitis $\mathrm{C}$ virus. Centers for Disease Control and Prevention. MMWR Recomm Rep 2003; 52: $12-5$.

[63] Chou R, Clark EC, Helfand M. Screening for hepatitis C virus infection: a review of services Task Force. Ann Intern Med 2004; 140: 465-79.

[64] Ferreira-Gonzalez, Shiffman ML. Use of diagnostic testing for managing hepatitis C virus infection. Semin Liver Dis 2004; 24(2): 9-18.

[65] Couroucé AM, Noel L, Barin F, et al. A comparative evaluation of the sensitivity of five anti-hepatitis $\mathrm{C}$ virus Immunoblot assays. Vox Sang 1998; 74: 217-24.

[66] Makuria AT, Raghuraman S, Burbelo PD, et al. The clinical relevance of persistent recombinant immunoblot assayindeterminate reactions: insights into the natural history of hepatitis $C$ virus infection and implications for donor counselling. Transfusion 2012; 52(9): 1940-8.

[67] Carreño-García V, Bartolomé-Nebreda J, Castillo-Aguilar I, Quiroga-Estévez JA. Infección oculta por el virus de la hepatitis C. Enferm Infecc Microbiol Clin 2011; 29(3): 14-9.

[68] Bouvier-Alias M, Patel K, Dahari H, et al. Clinical utility of total $\mathrm{HCV}$ core antigen quantification: a new indirect marker of $\mathrm{HCV}$ replication. Hepatology 2002; 36(1): 211-8.

[69] Peterson J, Green G, Iida K, et al. Detection of hepatitis C core antigen in the antibody negative 'window' phase of hepatitis $\mathrm{C}$ infection. Vox Sang 2000; 78(2): 80-5.

[70] Leary TP, Gutierrez RA, Muerhoff AS, Birkenmeyer LG, Desai SM, Dawson GJ. A chemiluminescent, magnetic particle based immunoassay for the detection of hepatitis $\mathrm{C}$ virus core antigen in human serum or plasma. J Med Virol 2006; 78(11): 1436-40.
[71] Tanaka Y, Takagi K, Fujihara T, et al. High stability of enzyme immunoassay for hepatitis $\mathrm{C}$ virus core antigen-evaluation before and after incubation at room temperature. Hepatol Res 2003; 26(4): 261-7.

[72] Laperche $\mathrm{S}$, Elghouzzi $\mathrm{MH}$, Morel $\mathrm{P}$, et al. Is an assay for simultaneous detection of hepatitis $\mathrm{C}$ virus core antigen and antibody a valuable alternative to nucleic acid testing? Transfusion 2005; 45: 1965-72

[73] Muerhoff AS, Jiang L, Shah DO, et al. Detection of HCV core antigen in human serum and plasma with an automated chemiluminescent immunoassay. Transfusion 2002; 42(3): 349-56

[74] Aoyagi K, Ohue C, Iida K, et al. Development of a simple and highly sensitive enzyme immunoassay for hepatitis $\mathrm{C}$ virus core antigen. J Clin Microbiol 1999; 37(6): 1802-8

[75] Tokita H, Kaufmann GR, Matsubayashi M, et al. Hepatitis C virus core mutations reduce the sensitivity of a fluorescence enzyme immunoassay. J Virol 2000; 74(23): 11347-58.

[76] Miedouge M, Saune K, Kamar N, Rieu M, Rostaing L, Izopet J. Analytical evaluation of $\mathrm{HCV}$ core antigen and interest for screening in haemodialysis patients. J Clin Virol 2010; 48: 18-21.

[77] Maynard M, Pradat P, Berthillon P, et al. Clinical relevance of total $\mathrm{HCV}$ core antigen testing for hepatitis $\mathrm{C}$ monitoring and for predicting patients' response to therapy. J Viral Hepat 2003; 10(4): 318-23.

[78] EASL International Consensus Conference on Hepatitis C. Paris, 26-28, February 1999, Consensus Statement. European Association for the Study of the Liver. J Hepatol 1999; 30(5): 956-61.

[79] Tillmann HL, Wiegand J, Glomb I, et al. Diagnostic algorithm for chronic hepatitis $\mathrm{C}$ virus infection: role of the new $\mathrm{HCV}$-core antigen assay. Z Gastroenterol 2005; 43(1): 11-6.

[80] Morota K, Fujinami R, Kinukawa H, et al. A new sensitive and automated chemiluminescent microparticle immunoassay for quantitative determination of hepatitis $\mathrm{C}$ virus core antigen. J Virol Methods 2009; 157(1): 8-14

[81] Carithers RL, Marquardt A, Gretch DR. Diagnostic testing for hepatitis C. Semin Liver Dis 2000; 20: 159-71.

[82] Saldanha J, Heath A, Aberham C, et al. World Health Organization collaborative study to establish a replacement WHO international standard for hepatitis $\mathrm{C}$ virus RNA nucleic acid amplification technology assays. Vox Sang 2005; 88(3): 202-4.

[83] Chevaliez S, Rodriguez C, Pawlotsky JM. New virologic tools for management of chronic hepatitis B and C. Gastroenterology 2012; 142(6): 1303-13e1.

[84] Le Guillou-Guillemette H, Lunel-Fabiani F. Detection and quantification of serum or plasma HCV RNA: mini review of commercially available assays. Methods Mol Biol 2009; 510: 3-14.

[85] Werhren J, Kau A, BC, Göbel R, Zeuzem S, Sarrazin C. Differences between Two Real-Time PCR-based hepatitis $\mathrm{C}$ virus (HCV) assays (Real Time HCV and Cobas AmpliPrep/Cobas TaqMan) and one signal amplification assay (Versant HCV RNA 3.0) for RNA detection and quantification. J Clin Microbiol 2008; 46: 3880-91.

[86] Krajden M, Ziermann R, Khan A, et al. Qualitative detection of hepatitis C virus RNA: comparison of analytical sensitivity, clinical performance, and workflow of the cobas amplicor HCV test version 2.0 and the HCV RNA transcription-mediated amplification qualitative assay. J Clin Microbiol 2002; 40(8): 290307.

[87] Hendricks DA, Friesenhahn M, Tanimoto L, Goergen B, Dodge D, Comanor L. Multicenter evaluation of the Versant HCV RNA qualitative assay for detection of hepatitis $\mathrm{C}$ virus RNA. J Clin Microbiol 2003; 41: 651-6.

[88] Sarrazin C. Highly sensitive hepatitis C virus RNA detection methods: molecular backgrounds and clinical significance. J Clin Virol 2002; 25: S23-9.

[89] Ghany MG, Strader DB, Thomas DL, Seeff B. Diagnosis, management, and treatment of hepatitis $C$ : an update. Hepatology 2009 ; 49: 1335-74.

[90] Michelin BD, Muller Z, StelzlE, Marth E, Kessler HH. Evaluation of the Abbott Real Time HCV assay for quantitative detection of hepatitis C virus RNA. J Clin Virol 2007; 38: 96-100.

[91] Amendola A, Coen S, Belladonna S, Pulvirenti FR, Clemens JM, Capobianchi MR. Improving clinical laboratory efficiency: a timemotion evaluation of the Abbott m2000 RealTime and Roche COBAS AmpliPrep/COBAS TaqMan PCR systems for the 
simultaneous quantitation of HIV-1 RNA and HCV RNA. Clin Chem Lab Med 2011; 49(8): 1283-8.

[92] Chevaliez S, Bouvier-Alias M, Brillet R, Pawlostky JM. Overestimation and underestimation of hepatitis C virus RNA levels in a widely used real-time polymerase chain reaction-based method. Hepatology 2007; 46: 22-31.

[93] Espy MJ, Uhl JR, Sloan LM, et al. Real-Time PCR in Clinical Microbiology: applications for routine laboratory testing. Clin Microbiol Rev 2006; 19(3): 595.

[94] Pawlotsky JM. Molecular diagnosis of viral hepatitis. Gastroenterology 2002; 122: 1554-68.

[95] Richter SS. Laboratory assays for diagnosis and management of hepatitis C virus infection. J Clin Microbiol 2002; 40(12): 4407-12.

[96] Elbeik TR. Delassandro YM, Chen A, Soutchkov SV, Loftus RA, Beringer S. Global cost modeling analysis of HIV-1 and HCV viral load assays. Expert Rev Phamacoecon Outcomes Res 2003; 3: 383407.

[97] Grody WW, Nakamura RM, Kiechle FL, Strom C. Molecular Diagnostics: Techniques and Applications for the Clinical Laboratory. USA: Academic Press 2009.

[98] Al Olaby RR, Azzazy HM. Hepatitis C virus RNA assays: current and emerging technologies and their clinical applications. Expert Rev Mol Diagn 2011; 11(1): 53-64.

[99] Laperche S, Lunel F, Izopet J, et al. Comparison of hepatitis C virus NS5b and 5'noncoding gene sequencing methods in a multicenter study. J Clin Microbiol 2005; 43: 733-9.

[100] Gault E, Soussan P, Morice Y, et al. Evaluation of a New Serotyping Assay for Detection of Anti-Hepatitis C Virus TypeSpecific Antibodies in Serum Samples. J Clin Microbiol 2003; 41(5): 2084-7.

[101] Simmonds P, Holmes EC, Cha T-A, et al. Classification of hepatitis $\mathrm{C}$ virus into six major genotypes and a series of subtypes by phylogenetic analysis of NS-5 region. J Gen Virol 1993; 74: 2391-9.

[102] Okamoto H, Sugiyama Y, Okada S, et al. Typing hepatitis C virus by polymerase chain reaction with type-specific primers: application to clinical surveys and tracing infectious sources. J Gen Virol 1992; 73: 673-9.
[103] Stuyver L, Wyseur A, Van Arnherm W, Hernandez F, Maertens G. Second-generation line probe assay for hepatitis $\mathrm{C}$ virus genotyping. J Clin Microbiol 1996; 34: 2259-66.

[104] Nakao T, Enomoto N, Takada N, Takada A, Date T. Typing of hepatitis $\mathrm{C}$ virus genome by restriction fragment length polymorphism. J Gen Virol 1991; 72: 2105-12.

[105] White PA, Zhai X, Carter I, Zhao Y, Rawlison WD. Simplified hepatits $\mathrm{C}$ virus genotyping by heteroduplex mobility analysis. $\mathrm{J}$ Clin Microbiol 2000; 38: 477-82.

[106] Schroter M, Zollner B, Schafer P, Landt O, Laufs R, Feucht HH. Genotyping of hepatitis $C$ virus types $1,2,3$ and 4 by one-step LightCycler methods using three different pairs of hybridization probes. J Clin Microbiol 2002; 40: 2046-50.

[107] Halfon P, Trimoulet P, Bourliere M, et al. Hepatitis C virus genotyping based on $5^{\prime}$ noncoding sequence analysis (Trugene). $\mathrm{J}$ Clin Microbiol 2001; 39(5): 1771-3.

[108] Bouchardeau F, Cantaloube JF, Chevaliez S et al. Improvement of hepatitis $\mathrm{C}$ virus (HCV) genotype determination with the new version of the INNO-LiPA HCV assay. J Clin Microbiol 2007; 45(4): 1140-5.

[109] Germer JJ, Majewski DW, Yung B, Mitchell PS, Yao JDC Evaluation of the Invader assay for genotyping hepatitis $\mathrm{C}$ virus. J Clin Microbiol 2006; 44: 318-23.

[110] Rho J, Ryu JS, Hur W, et al. Hepatitis C virus (HCV) genotyping by annealing reverse transcription-PCR products with genotypespecific capture probes. J Microbiol 2008; 46 (1): 81-7.

[111] Cook L, Sullivan KW, Krantz EM, Bagabag A, Jerome KR Multiplex realtime reverse transcription-PCR assay for determination of hepatitis $\mathrm{C}$ virus genotypes. J Clin Microbiol 2006; 44: 4149-56.

[112] Antonishyn NA, Ast VM, McDonald RR, et al. Rapid genotyping of hepatitis $\mathrm{C}$ virus by primer-specific extension analysis. J Clin Microbiol 2005; 43(10): 5158-63.

[113] Duarte CAB, Foti L, Nakatani SM, et al. Hepatitis C Virus Genotyping Method Based on Liquid Microarray. PLoS One 2010; 5(9): e12822.

[114] Deweerdt S. A testing journey. Nature 2011; 474: S20-S21.

[115] Shawky SM, Bald D, Azzazy HME. Direct detection of unamplified hepatitisC virus RNA using unmodified gold nanoparticles. Clin Biochem 2010; 43: 1163-8.

(C) Cabezas-Fernandez and Cabeza-Barrera; Licensee Bentham Open.

This is an open access article licensed under the terms of the Creative Commons Attribution Non-Commercial License (http: //creativecommons.org/licenses/by$\mathrm{nc} / 3.0 /$ ) which permits unrestricted, non-commercial use, distribution and reproduction in any medium, provided the work is properly cited. 